Basic Electrical Installations 
By the same author

ELECTRICAL INSTALLATIONS AND REGULATIONS 


\section{BASIC ELECTRICAL INSTALLATIONS}

\section{Michael Neidle}

Associate Member of the Institution of Electrical Engineers,

T. Eng. (C.E.I), F.I.T.E, A.S.E.E. (Dipl.)

\section{Second Edition}

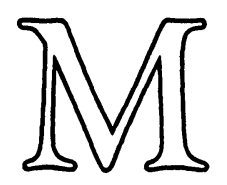


() Michael Neidle 1977, 1979

All rights reserved. No part of this publication may be reproduced or transmitted in any form or by any means without permission.

First edition 1977

Second edition 1979

Published by

THE MACMILLAN PRESS LTD

London and Basingstoke

Associated companies in Delhi Dublin

Hong Kong Johannesburg Lagos Melbourne

New York Singapore and Tokyo

ISBN 978-1-349-81411-4 ISBN 978-1-349-81409-1 (eBook)

DOI 10.1007/978-1-349-81409-1

To Hetty,

for a life-long inspiration

The paperback edition of this book is sold subject to the condition that it shall not, by way of trade or otherwise, be lent, resold, hired out, or otherwise disposed of without the publisher's prior consent in any form of binding other than that in which it is published and without a similar condition including this condition being imposed on the subsequent purchaser. 


\section{CONTENTS}

Preface

Electrical Installation Symbols (BS 3939)

\section{THE ELECTRICAL CIRCUIT}

1.1 Atoms and Electrons

1.2 The Free Electron

1.3 Units

1.4 Ohm's Law

1.5 Series Circuit

1.6 Parallel Circuit

1.7 Power

1.8 Exercises

\section{SUPPLIES}

2.1 Voltage Bands

2.2 Underground Cables

2.3 Main Installation Controls

2.4 Close Protection

2.5 Earth-leakage Protection

2.6 Intakes

2.7 Off-peak and White Meter

2.8 Voltage Drop

2.930 A Ring Circuit

2.10 Exercises

\section{SHEATHED WIRING SYSTEMS}

3.1 Polyvinyl-chloride-sheathed Cables

3.2 Use of Joint Boxes

3.3 Fixings

3.4 Carcase Wiring

3.5 Clips

3.6 Terminations

3.7 Mineral-insulated Metal-sheathed Cables

3.8 Temperature Limits

3.9 Corrosion vii

3.10 Special Applications

3.11 Exercises

21

viii

4 CONDUIT SYSTEMS

4.1 Steel Conduits 23

4.2 Boxes 23

4.3 Threading and Reamering 23

4.4 Bending 24

4.5 Continuity 25

4.6 Wiring 25

4.7 Eddy Currents 26

4.8 Space Factor 26

4.9 Lighting Circuits 26

4.10 Flexible Conduit 26

4.11 Threadless steel conduits 27

4.12 PVC Conduits 27

4.13 Installation of PVC Conduits 27

4.14 Earthing 27

4.15 Exercises $\quad 28$

5 TRUNKING WORK 30

5.1 Overhead Busbar Trunking 30

5.2 Cable Trunking 30

5.3 Vertical and Horizontal Cable Runs 31

5.4 Corrosion 31

5.5 Bonding 31

5.6 Skirting Trunking 31

5.7 Space Factor 32

5.8 Ducting 32

5.9 Exercises 33

6 LIGHTING 34

6.1 Tungsten Lamps 34

6.2 Lamp Fuses 34

6.3 Types of Lamp 34

6.4 Final Sub-circuits 35 

6.5 Luminaires
6.6 Lampholders
6.7 Ceiling Roses
6.8 Heat Protection
6.9 Dimmers
6.10 Setting-out Lighting Points
6.11 Bathrooms
6.12 Fluorescent Lighting
6.13 Maintenance
6.14 Fluorescent-lamp Faults
6.15 Exercises

\section{HEATING}

\subsection{Calculations}

7.2 Room Heating

7.3 Conduction

7.4 Thermostats

7.5 Storage Heaters

7.6 Water Heating

7.7 Exercises

\section{TESTING}

8.1 Basic Principles

8.2 Polarity

8.3 Earthing

8.4 Insulation Resistance

8.5 Ring-circuit Integrity

8.6 Certification

8.7 Appliances

8.8 Ammeters and Voltmeters

8.9 Exercises

9 EXTRA-LOW-VOLTAGE SUPPLIES
9.1 Segregation
9.2 The Primary Cell
9.3 Secondary Cells
9.4 Electromotive Force
9.5 Bells

41

50
9.6 Indicator Boards 52

9.7 Burglar Alarms and Fire Alarms

9.8 Exercises 53

10 ALTERNATING CURRENT

10.1 The A.C. Cycle 55

10.2 R.M.S. Values $\quad 55$

10.3 A.C. Slow-break Switches 56

10.4 Lagging Currents $\quad 56$

10.5 Eddy Currents $\quad 56$

10.6 Power Factor $\quad 56$

10.7 Power-factor Improvement $\quad 57$

10.8 Transformers $\quad 57$

10.9 Three-phase Supplies $\quad 58$

10.10Exercises $\quad 58$

11 CARE AND SAFETY 60

11.1 Handling Materials and Equipment 60

11.2 Tool Care 60

11.3 Safety at Work 61

11.4 Health and Safety 62

11.5 Electric-shock Treatment 63

11.6 Fire Protection 64

11.7 Exercises 64

12 THE ELECTRICAL INSTALLATION INDUSTRY 65

12.1 Electrical Installations in a Changing World 65

12.2 Self-advancement $\quad 65$

12.3 Structure of the Industry 65

12.4 Joint Industry Board 68

12.5 Other Organisations 68

12.6 Organising the Work 69

12.7 Site Diary and Daywork Sheets 69

12.8 Computer Usage $\quad 69$

12.9 Exercises $\quad 69$

Answers to Exercises $\quad 71$

$\begin{array}{ll}\text { Index } & 72\end{array}$ 


\section{PREFACE}

The object of this book is to lay a firm foundation for an understanding of electrical installation techniques. While it is primarily designed as a textbook for students taking the Part 1 Certificate examination in Electrical Installation Work, City and Guilds Course 236, and so set them on the road to a worthwhile career, it is hoped to have a wider appeal. People studying allied subjects, such as City and Guilds Course 200, and those engaged in electrical wiring, who may have missed their technical studies, will find the material particularly useful. Technical college lecturers will also find it of value for lesson preparation.

A close study of the text and worked examples shows that the questions are approached in a clear and orderly manner. This should assist in giving a sound and logical training for tackling other problems, especially those encountered in real installation situations.

While the wiring sections are firmly based on the I.E.E. Wiring Regulations, full account has been taken of the
Statutory Electrical Equipment (Safety) Regulations 1975.

The social content of the last two chapters may seem unusual in a technical book. It is, however, in line with the City and Guilds Syllabus, which encourages students to have some realisation of the difficulties and challenges brought about in a rapidly changing world.

Grateful acknowledgement is given to the following companies and authorities: B.I.C.C. Ltd, British Standards Institution, City and Guilds of London Institute, Electrical Contractors Association, Evershed and Vignoles Ltd, Institution of Electrical Engineers, Ottermill Ltd, Simplex Power Centre, Tenby Ltd.

In this second edition, material on daywork sheets and site diaries has been added and the text has been brought thoroughly up to date. Working through the additional end-ofchapter exercises will consolidate the knowledge gained from an understanding of the book contents. 


\section{ELECTRICAL INSTALLATION SYMBOLS (BS 3939)}

\begin{tabular}{|l|l|}
\hline $\begin{array}{l}\text { main control } \\
\text { or intake point }\end{array}$ & \\
\hline $\begin{array}{l}\text { distribution board or point } \\
\text { note: the circuits controlled } \\
\text { by the distribution board may } \\
\text { be shown by the eddition of } \\
\text { an appropriate qualifying } \\
\text { symbol or reference }\end{array}$ \\
\hline $\begin{array}{l}\text { examples: heating } \\
\text { lighting }\end{array}$ \\
\hline ventilating
\end{tabular}

\begin{tabular}{|l|l|}
\hline heater: type to be specified & \\
\hline motor : general symbol & \\
\hline generator : general symbol & \\
\hline thermostat : block symbol & \\
\hline switch with pilot lamp & \\
\hline period limiting switch & \\
\hline time switch & \\
\hline $\begin{array}{l}\text { regulating switch } \\
\text { eg. dimmer }\end{array}$ & \\
\hline socket outlet (mains): \\
general symbol
\end{tabular}

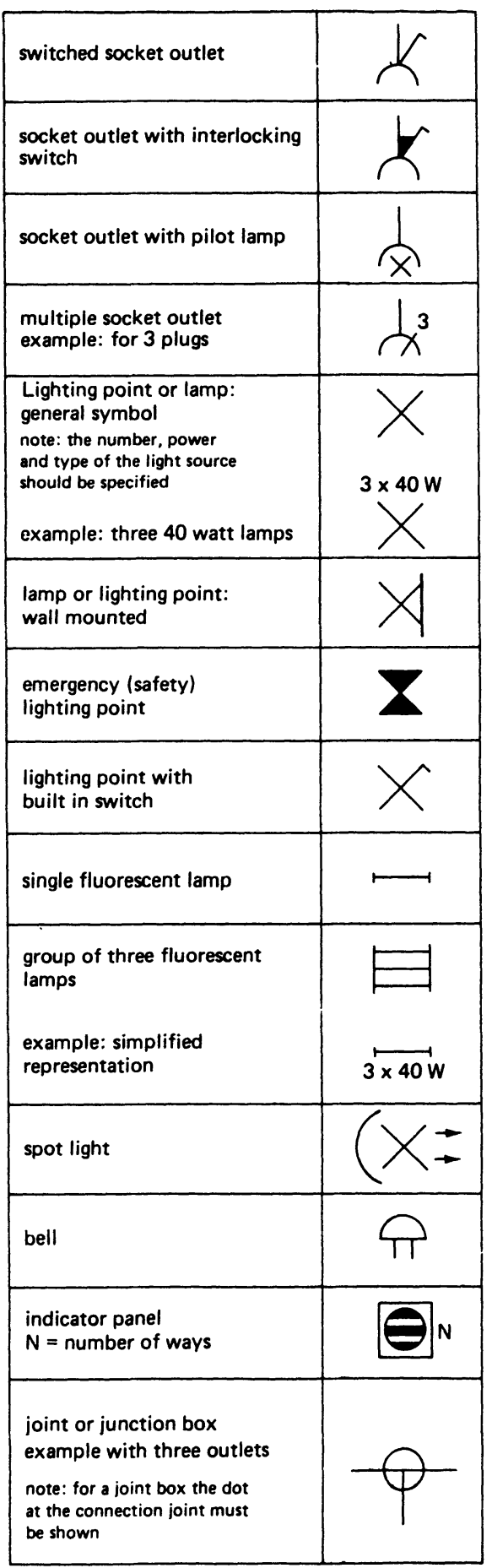

